\title{
Kinetics of thymocyte developmental process in fetal and neonatal mice
}

\author{
Shi Yun XIAO*, Yan LI*, Wei Feng CHEN** \\ Department of Immunology, School of Basic Medical Sciences, Peking University Health Science Center, 38 Xueyuan \\ Road, Beijing 100083, China
}

\begin{abstract}
Kinetics of thymocyte development in vivo during embryogenesis was pursued. The early development of thymocytes in the fetal and neonatal BALB/c mice was discontinuous, with four waves of cell proliferation occurring at fetal day (Fd) 14 to 17, Fd 18 to day (D) 1 after birth, D 2 to D 5 and D6 thereafter. The first three proliferation waves coincided with the generation of $\mathrm{CD} 4{ }^{\mathrm{hi}} \mathrm{CD} 8^{\mathrm{hi}}(\mathrm{DP}), \mathrm{TCR}^{+} \mathrm{CD} 4^{\mathrm{hi}} \mathrm{CD} 8^{-/ \mathrm{lo}}$ (CD4 SP), and $\mathrm{TCR}^{+} \mathrm{CD} 4^{-/ l o} \mathrm{CD} 8^{\text {int/hi }}$ (CD8 SP) thymocytes, respectively. The transition from DN to DP cells was further investigated and it was found out that there were two differential pathways via immature single positive (ISP) cells in the BALB/c mice, each functioning at different fetal ages. One is via TCR ${ }^{-} 4^{-}{ }^{-C D} 8^{+}$cells, occurring between $\mathrm{Fd} 15$ and $\mathrm{Fd} 17$ and the other is via TCR $\mathrm{CD}^{+} \mathrm{CD} 8^{-}$cells, occurring from $\mathrm{Fd} 17$ until birth. In contrast, the $\mathrm{TCR}^{-\mathrm{CD}} 4^{-} \mathrm{CD}^{+}$pathway dominated overwhelmingly in the $\mathrm{C} 57 \mathrm{BL} / 6$ mice. These findings shed new light on the hypothesis that the differential pathway preference varies with mouse strains. With respect to the shift in the intensity of CD4 and CD8 expression on thymocytes from fetal to adult mice, the TCR ${ }^{+} \mathrm{CD} 4{ }^{\text {hi }} \mathrm{CD}^{-}$ ${ }^{\text {lo }}$, and $\mathrm{TCR}^{+} \mathrm{CD}^{-/ \mathrm{lo}} \mathrm{CD}^{\text {int/hi }}$ subsets might be equivalent to the medullary type $\mathrm{TCR}^{+} \mathrm{CD} 4 / \mathrm{CD} 8 \mathrm{SP}$ cells.
\end{abstract}

Key words: fetal thymus, neonatal mice, thymocyte ontogeny.

\section{INTRODUCTION}

$\mathrm{T}$ cell development within the thymus proceeds via major steps of TCR gene rearrangement, thymic selection, and functional maturation. In this process, developing cells proliferate, differentiate and are selected for the generation of immunocompetent $\mathrm{T}$ cells. During fetal development, common lymphoid progenitors (CLPs) colonize the thymus epithelial rudiment and develop into thymocytes[1].

*The first two authors contributed equally to this study.

** Correspondence: Prof. Wei Feng CHEN, Department of Immunology, School of Basic Medical Sciences, Peking University Health Science Center, 38 Xueyuan Road, Beijing 100083, China. Tel: 0086-10-62092593 Fax: 0086-10-62091436

E-mail: wfchen@public.bta.net.cn

Abbreviations: BSS, balanced salt solution; DN, double-negative; DP, double-positive; FCS, fetal calf serum; NCS, newborn calf serum; SP, single-positive.

Received Feb-26-2003 Revised April-28-2003 Accepted May-22003
The dynamics of thymus colonization and the differentiation potential of progenitors migrating into the thymus have long been an issue of interest. In mice, the first inflow of CLPs has been observed to occur on fetal day 10 to 12[2-4]. Differentiation of thymocytes has been studied intensively by tracing the development of four major subsets of CD4CD8(DN), $\mathrm{CD}^{+} \mathrm{CD}^{+}(\mathrm{DP}), \mathrm{CD}^{+}{ }^{+} \mathrm{CD} 8{ }^{-}$, and $\mathrm{CD} 4{ }^{-\mathrm{CD}} 8^{+}$ (SP) cells. DN cells are the only intrathymic precursors and the only cell subset present in the thymus before Fd 14[5]. DP cells are under strict thymic selection and give rise to SP cells. SP cells are further divided into mature and immature CD4/CD8 SP based on TCR expression. $\mathrm{TCR}^{+} \mathrm{CD} 4 \mathrm{SP}$ and $\mathrm{TCR}^{+} \mathrm{CD} 8 \mathrm{SP}$ cells are ready for emigration to the periphery after further maturation into immunocompetent cells in the medulla[6]. The immature SP cells, with the phenotype of $\mathrm{CD} 4^{+} \mathrm{CD} 8^{-} / \mathrm{CD} 4{ }^{-} \mathrm{CD} 8^{+} \mathrm{TCR}^{-/ l o}$, 
represent the transitional state between $\mathrm{DN}$ and $\mathrm{DP}$ cells[7-9]. In this study, we additionally defined several transitional subsets according to CD4, CD8 and TCR expression and tried to delineate the developmental pathway of thymocytes in the fetal and neonatal mice, in an attempt to better understand early events during the thymocyte ontogeny.

\section{MATERIALS AND METHODS}

\section{Mice}

$\mathrm{BALB} / \mathrm{c}$ or $\mathrm{C} 57 \mathrm{BL} / 6$ mice were bred in the Animal Breeding Laboratory, Institute of Genetics, Chinese Academy of Sciences (Beijing, China). Male and female mice were mated overnight and females were examined the next morning. The day on which a vaginal plug was observed was taken as day 0 of gestation. Full term birth took place on day 19. Ages of fetal mice are noted as fetal day (Fd) and day (D) after birth. Adult BALB/c mice of 5-6 weeks' old were also from the above animal breeding laboratory.

\section{Monoclonal antibodies}

Antibodies (mAb) used for flow cytometry analysis (FACS) were: phycoerythrin (PE)-conjugated anti-mouse CD4 (anti-mCD4) (GK1.5), peridinin chlorophyll-a protein (PerCP)-conjugated antimCD8 (53-6.7), allophycocyanin (APC)-conjugated anti-mTCR $\beta$ (H57-597). All fluorescent-conjugated antibodies were purchased from PharMingen (San Diego, CA). MAbs used for cytotoxic procedures were: anti-mCD4 (RL172.4), anti-mCD8 (3.155) and antimCD3 (145-2C11). MAbs for panning use were: anti-mCD4 (GK1. $5)$, anti-mCD8 (3.155). These mAbs were produced in our laboratory as ascites.

\section{Cell preparation}

Pooled fetal thymi were homogenized by a syringe plunger and nylon mesh. Single cell suspensions in cold RPMI-1640 medium (Gibco, Grand Island, NY) containing 5\% newborn calf serum (NCS) were filtered through nylon mesh to remove clumped debris. Cells were washed twice and resuspended in the same medium for staining.

To obtain immature single positive cells, total thymocytes from Fd 15-17 mice were pooled respectively and treated by complement-mediated killing after incubation with anti-mCD3 (145-2C11) together with either anti-mCD4 (RL172.4) or anti-mCD8 (3.155) $\mathrm{mAb}$ in order to enrich $\mathrm{CD} 3^{-\mathrm{CD}} 4^{-} \mathrm{CD} 8^{+}$or $\mathrm{CD} 3^{-} \mathrm{CD} 4^{+} \mathrm{CD} 8^{-}$cells, respectively. After two cycles of killing and the dead cells removed by density centrifugation, the viable cells were further enriched by panning method using anti-mCD8 (3.155) or anti-mCD4 (RL172. 4) mAb-coated dishes. Cells were poured onto the dishes and incubated at $4^{\circ} \mathrm{C}$ for $40 \mathrm{~min}$. Non-adhereent cells were removed; the bound cells were recovered by flushing and collected as CD3- and CD4- depleted cells from anti-mCD8 mAb-coated dishes; or as CD3and CD8-depleted cells from anti-mCD4 mAb-coated dishes. After treatment with these series of protocols, the purity was $>97 \%$.

\section{Short term in vitro culture}

Cells of each subset isolated were cultured at $5 \times 10^{6} / \mathrm{ml} \mathrm{RPMI-}$ 1640 medium containing $10 \% \mathrm{FCS}$ in a $5 \% \mathrm{CO}_{2}$ incubator at $37^{\circ} \mathrm{C}$ for $24 \mathrm{~h}$. After incubation, the cells were harvested and stained with fluorescent-conjugated anti-CD4 and anti-CD8 mAbs for FACS analysis.

\section{Flow cytometry}

The thymocytes were diluted to a concentration of $1 \times 10^{6}$ cells/ $\mathrm{ml}$ in balanced salt solution (BBS) containing $2 \%$ NCS. Then, the individual samples were stained separately with a panel of mAbs as indicated. Negative controls included isotype $\mathrm{mAb}$ conjugated with the corresponding fluorochrome. Single color staining with each different fluorescent conjugated $\mathrm{Ab}$ was applied to adjust the compensation. After the final wash, cells were resuspended in 500 $\mu \mathrm{l}$ of BSS and analyzed by FACS Calibur (Becton Dickinson, Mountain View, CA). Dead cells were excluded from analysis by setting electronic gates with FSC and SSC. Data acquisition and analysis were performed using CellQuest software (Becton Dickinson, Mountain View, CA).

\section{RESULTS}

\section{Discontinuous waves of thymocyte proliferation}

Thymocytes were harvested from BALB/c mice of Fd 14 to D 14, and the cell numbers were counted. The increase of total thymocyte number during this period was discontinuous and could be characterized as four proliferation waves. The first wave of proliferation occurred between Fd 14 and Fd 17, when the total number of thymocytes increased from $2 \times$

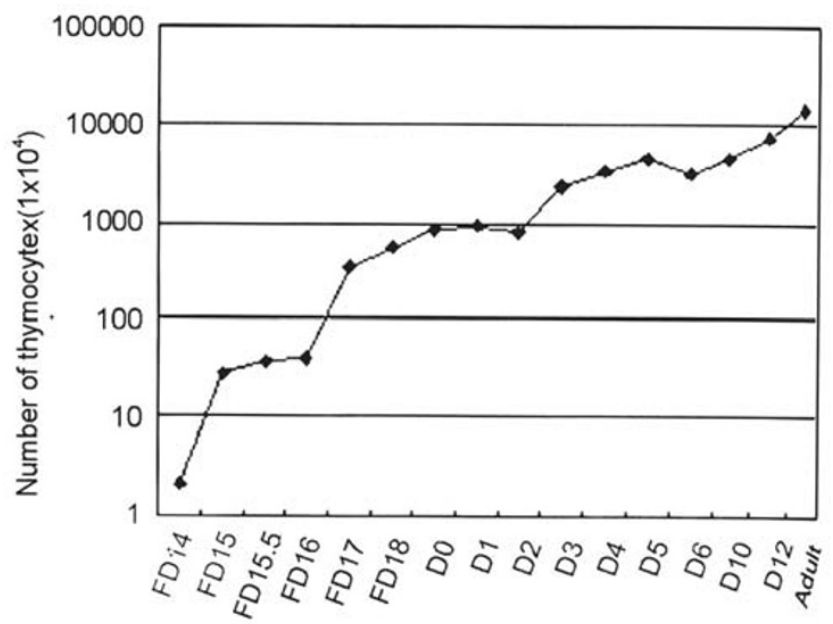

Fig 1. Discontinuous increase in the number of thymocytes. Total thymocyte numbers were counted at various fetal and neonatal ages. Means of three to five determinations including at least three mice of each age (SEM was always lower than $10 \%$ of the mean). 
$10^{4}$ to $3.4 \times 10^{6}$ per mouse. The second wave occurred between $\mathrm{Fd} 18$ and $\mathrm{D} 1$ with the thymocyte number doubled. The third wave occurred between D 2 and D 5 with a total cell number of $7 \times 10^{7}$ on D 5 . The fourth proliferation wave was observed between D 6 and D 14, when the number of thymocytes increased to about $1.3 \times 10^{8}$, indicating that the generation of thymocytes in fetal and neonatal mice proceeds in a stepwise manner (Fig 1).

Generation of $D P\left(C D 4^{l o} C D 8^{l o} / C D 4^{l o} C D 8^{\text {int }} /\right.$ $C D 4^{h i} C D 8^{h i}$ ) cells during the first wave of proliferation

Thymocytes from fetal and neonatal mice at different ages were three-color stained with anti-mCD4, anti-mCD 8 and anti-mTCRb mAbs for flow cytometry. Based on the expression level of CD4 and CD8, thymocytes from DN to SP stages could be divided into seven groups: $\mathrm{CD} 4^{-\mathrm{CD}} 8^{-}, \mathrm{CD} 4^{-\mathrm{CD}} 8^{\mathrm{lo} / \mathrm{int}}$, $\mathrm{CD} 4^{\mathrm{lo} /{ }^{\mathrm{int}} \mathrm{CD}} 8^{-}, \mathrm{CD} 4^{\mathrm{lo}} \mathrm{CD} 8^{\mathrm{lo}}, \mathrm{CD} 4^{\mathrm{lo} /-} \mathrm{CD} 8^{\text {int }}, \mathrm{CD} 4^{\mathrm{hi}} \mathrm{CD} 8^{\mathrm{lo} /-}$ and $\mathrm{CD} 4{ }^{\text {hi }} \mathrm{CD} 8^{\text {hi }}$ cells (Fig 2). The percentages of each group in total cells are listed in Tab 1.

All thymocytes bore the phenotype of TCR CD4-CD8 ${ }^{-}$at Fd 14. This was followed by the appearance of immature CD4 SP cells $\left(\mathrm{TCR}^{-/ / 0} \mathrm{CD} 4^{\mathrm{lo} /}\right.$ ${ }^{\text {int }} \mathrm{CD}^{-}$) at $\mathrm{Fd} 14.5$ to $\mathrm{Fd} 15$, which constituted $3.5 \%$ of total cells and only $2 \%$ of which were TCR $^{+}$. TCR $\mathrm{CD} 4^{\text {lo/int }} \mathrm{CD} 8$ cells increased gradually from $\mathrm{Fd} 14.5$ to Fd 16, approaching a maximum of $24.4 \%$ during the first proliferation wave (Tab 1, Fig 2). Meanwhile, the percentage of $\mathrm{TCRb}^{+}$cells remained at $2 \%$ (data not shown). Half a day later than $\mathrm{CD} 4^{\mathrm{lo} / \mathrm{int}} \mathrm{CD} 8^{-}$cells, i.e., at $\mathrm{Fd} 15$, the immature $\mathrm{CD} 8 \mathrm{SP}$ cells $\left(\mathrm{TCR}^{-/ \mathrm{lo}} \mathrm{CD} 4^{-}\right.$ CD8 $\left.{ }^{\text {lo/int }}\right)$ occurred and constituted $13 \%$ of total cells and $30 \%$ of them were $\mathrm{TCRb}^{+}$(data not shown). Remarkably, more immature CD8 SP $\left(\mathrm{TCR}^{-/ / 10} \mathrm{CD} 4{ }^{-}\right.$ CD8 ${ }^{\text {lo/int }}$ ) cells expressed TCRb than did the immature CD4 SP $\left(\mathrm{TCR}^{-/ \mathrm{lo}} \mathrm{CD} 4^{\mathrm{lo}} \mathrm{CD} 8^{-}\right)$cells. At Fd 15, another two subsets of $\mathrm{CD} 4^{\mathrm{lo}} \mathrm{CD} 8^{\mathrm{lo}}$ and $\mathrm{CD} 4^{\mathrm{lo}} \mathrm{CD} 8^{\text {int/hi }}$ cells were observed and they accounted for $2.3 \%$ of total cells (Fig 2, Tab 1). At Fd 16, CD4CD8 ${ }^{\text {lo/int }}$ cells decreased while both $\mathrm{CD} 4{ }^{\mathrm{lo}} \mathrm{CD} 8^{\mathrm{lo}}$ and $\mathrm{CD} 4{ }^{\mathrm{lo}} \mathrm{CD} 8^{\text {int }}$ cells were

Tab 1. The percentages of distinct CD4/CD8 subsets in thymocyte population.

\begin{tabular}{|c|c|c|c|c|c|c|c|c|}
\hline Age & $\begin{array}{l}\text { Subset } \\
\text { (Region) }\end{array}$ & $\begin{array}{c}\text { CD48 } \\
\text { (R1) }\end{array}$ & $\begin{array}{c}\text { CD4-8 } 8^{\text {lo/int }} \\
\text { (R2) }\end{array}$ & $\begin{array}{c}\mathrm{CD}^{\text {lo/int }} 8^{-} \\
\text {(R3) }\end{array}$ & $\begin{array}{c}\mathrm{CD} 4^{\text {lo }} 8^{\text {lo }} \\
(\mathrm{R} 4)\end{array}$ & $\begin{array}{c}\mathrm{CD} 4^{\text {lo }} 8^{\text {int }} \\
\text { (R5) }\end{array}$ & $\begin{array}{c}\mathrm{CD}^{\text {hi }} 8^{\mathrm{lo} /-} \\
(\mathrm{R} 6)\end{array}$ & $\begin{array}{c}\mathrm{CD}^{\text {hi }} 8^{\text {hi }} \\
\text { (R7) }\end{array}$ \\
\hline Fd 14.5 & & 94.0 & 0 & 3.5 & 0 & 0 & 0 & 0 \\
\hline $\mathrm{Fd} 15$ & & 69.0 & 13.0 & 4.4 & 0.8 & 1.5 & 0 & 0 \\
\hline $\mathrm{Fd} 16$ & & 38.0 & 6.4 & 24.0 & 2.0 & 2.4 & 0.4 & 0.3 \\
\hline Fd17 & & 12.0 & 6.1 & 16.0 & 8.1 & 15.0 & 0.8 & 24.0 \\
\hline $\mathrm{Fd} 18$ & & 4.0 & 1.7 & 7.5 & 6.3 & 8.4 & 1.2 & 60.0 \\
\hline D 0 & & 3.3 & 1.1 & 5.8 & 7.3 & 4.2 & 7.1 & 63.0 \\
\hline D 1 & & 1.8 & 0.3 & 2.4 & 11.0 & 1.4 & 11.0 & 75.0 \\
\hline D 2 & & 2.9 & 1.0 & 5.1 & 5.6 & 4.3 & 22.0 & 52.0 \\
\hline D 3 & & 2.0 & 0.4 & 1.5 & 1.9 & 3.0 & 8.9 & 70.0 \\
\hline D 4 & & 2.2 & 0.4 & 2.0 & 2.0 & 3.3 & 8.3 & 78.0 \\
\hline D 5 & & 2.5 & 0.3 & 2.4 & 2.2 & 5.7 & 8.7 & 77.0 \\
\hline D 6 & & 2.6 & 0.3 & 1.7 & 2.1 & 2.9 & 6.6 & 77.0 \\
\hline D 10 & & 1.0 & 0.3 & 0.4 & 1.1 & 2.1 & 6.7 & 80.0 \\
\hline D 14 & & 1.2 & 0.3 & 0.6 & 1.3 & 3.4 & 7.6 & 78.0 \\
\hline Adult & & 0.4 & 0.5 & 1.4 & 2.2 & 3.1 & 10.0 & 72.0 \\
\hline
\end{tabular}

The regions in this table correspond to those defined in Fig 2. Mean of three determinations including at least three mice of each age (SEM was always lower than $10 \%$ of the mean). 
increased. Meanwhile, a new subset of CD $4^{\text {hi }} \mathrm{CD} 8^{\text {hi }}$ cells was generated $(0.3 \%)$, which brought the total number of DP cells (including $\mathrm{CD} 4{ }^{\mathrm{lo}} \mathrm{CD} 8^{\mathrm{lo}}$ and $\mathrm{CD} 4^{\text {lo }} \mathrm{CD}^{\text {int }}$ ) up to $4.7 \%$. At Fd 15 , there were $31 \%$ of $\mathrm{TCRb}^{+}$cells in the subsets of $\mathrm{CD} 4{ }^{\mathrm{lo}} \mathrm{CD} 8^{\text {lo }}$ and $\mathrm{CD} 4^{\text {lo }} \mathrm{CD}^{\text {int }}$. At Fd 16 , TCR $\beta^{+}$cells were $18 \%$ in the subsets of $\mathrm{CD} 4^{\text {lo }}{ }^{\circ} \mathrm{CD} 8^{\text {lo }}$ and $\mathrm{CD} 4{ }^{\text {lo }} \mathrm{CD} 8^{\text {int }}$ cells and $8.3 \%$ in the $\mathrm{CD} 4{ }^{\mathrm{hi}} \mathrm{CD} 8^{\mathrm{hi}}$ cells. Based on the following facts: (1) similar proportion of TCR $\beta^{+}$cells in DP and CD4 ${ }^{-}{ }^{-10} 8^{\text {loint }}$ cells, (2) increase of DP cells occurred at the same time as the decrease of $\mathrm{CD} 4{ }^{-} \mathrm{CD} 8^{\mathrm{lo} / \mathrm{int}}$ cells, (3) the flow from CD4 CD8 ${ }^{\text {lo/int }}$ to DP cells shown by FACS analysis (Fig 2), the DP cells generated in the first wave from $\mathrm{Fd} 14.5$ to $\mathrm{Fd} 16$ appear to be derived mainly from $\mathrm{CD} 4^{-\mathrm{CD}} 8^{\mathrm{lo} / \mathrm{int}}$ cells.

At $\mathrm{Fd} 17$, the proportion of $\mathrm{CD} 4^{\text {lo/int }} \mathrm{CD} 8^{-}$cells started to decrease progressively. On the other hand, the total number of $\mathrm{CD} 4^{\mathrm{lo}} \mathrm{CD} 8^{\mathrm{lo}}, \mathrm{CD} 4^{\mathrm{lo}} \mathrm{CD} 8^{\mathrm{int} / \mathrm{hi}}$ and $\mathrm{CD} 4{ }^{\text {hi }} \mathrm{CD} 8{ }^{\text {hi }}$ cells increased greatly from less than $10 \%$ at Fd 14.5-15 to about 50\% at Fd 17(Fig 2, Tab 1). Thus, the CD4 ${ }^{\text {lo/int }} \mathrm{CD} 8$ cells probably had differentiated into $\mathrm{CD} 4^{\text {lo }} \mathrm{CD} 8^{\text {lo }}$ cells and then into $\mathrm{CD} 4^{\text {lo }} \mathrm{CD} 8^{\text {int/ }}$ hi and $\mathrm{CD} 4^{\text {hi }} \mathrm{CD} 8^{\text {hi }}$ cells. After Fd 17 , the CD4-CD8 ${ }^{\text {lo/int }}$ cells decreased gradually and remained at a very low level until adulthood. Apparently, from Fd 17 onwards, the DP cells arose mainly from CD4 ${ }^{\text {lo/int }} \mathrm{CD} 8^{-}$
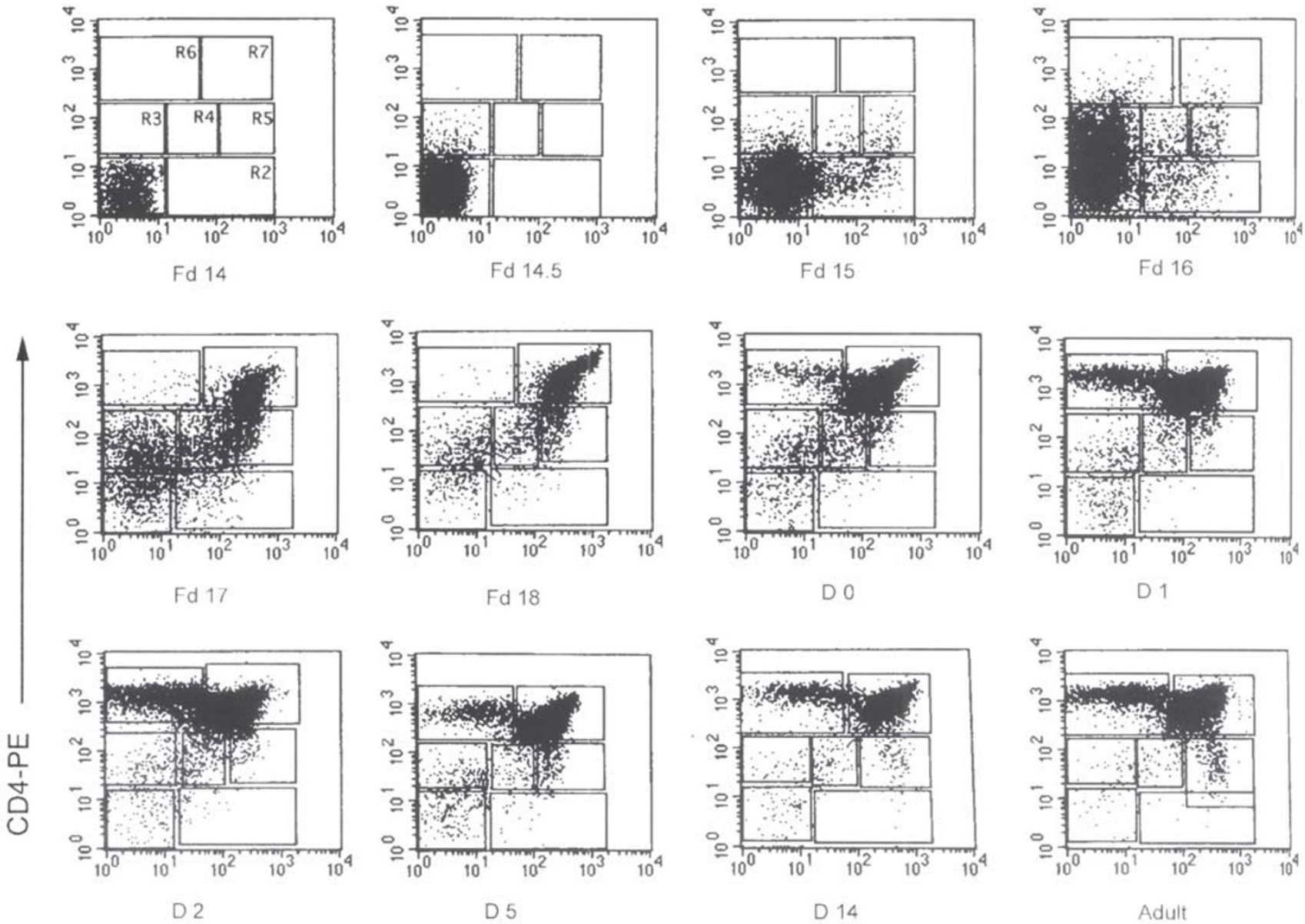

CD8-PerCP

Fig 2. Kinetics of the expression of CD4 and CD8 molecules on thymocytes from fetal and neonatal BALB/C mice. Thymocytes from fetal and neonatal mice were stained triply with PE-conjugated anti-CD4, PerCP-conjugated antiCD8 and APC-conjugated anti-TCR. On the basis of CD4/CD8 fluorescent intensity, seven major transitional subsets were defined as follows: CD4-8 $8^{-}(\mathrm{R} 1), \mathrm{CD} 4^{-} 8^{\mathrm{lo} / \mathrm{int}}(\mathrm{R} 2), \mathrm{CD} 4^{\mathrm{lo} / \mathrm{int}} 8^{-}(\mathrm{R} 3), \mathrm{CD} 4^{\text {lo }} 8^{\text {lo }}(\mathrm{R} 4), \mathrm{CD} 4^{\text {lo }} 8^{\mathrm{int}}(\mathrm{R} 5), \mathrm{CD} 4^{\mathrm{hi}} 8^{\mathrm{lo} /-}(\mathrm{R} 6)$ and $\mathrm{CD} 4^{\text {hi }} 8^{\text {hi }}(\mathrm{R} 7)$ thymocytes. These data are representative of three determinations. 
cells. And anotherimportant observation in the present study was that both $\mathrm{TCR}^{-} \mathrm{CD} 4^{-\mathrm{CD}} 8^{\text {lo/int }}$ and $\mathrm{TCR}^{-\mathrm{CD}} 4^{\text {lo/int }} \mathrm{CD} 8^{-}$cells seemed to generate DP cells, but developed at distinct time points of gestation. Conceivably, the DN cells differentiating into DP cells during early ontogeny in the $\mathrm{BALB} / \mathrm{c}$ mice may proceed through two distinct pathways.

Generation of $\mathrm{TCR}^{+} \mathrm{CD} 4^{\text {hi }} \mathrm{CD} 8^{\text {lo/- }}$ cells during the second wave of cell proliferation

The second wave of cell proliferation continued from Fd 18 to D 1 (Tab 1, Fig 1 and Fig 2,). During this period, immature CD8SP (TCR ${ }^{-} \mathrm{CD} 4^{-\mathrm{CD}} 8^{\mathrm{lo} / \mathrm{int}}$ ) cells decreased rapidly from $\mathrm{Fd} 17$ to $\mathrm{Fd} 18$ and then remained at $0.3 \%$ until adulthood. It became evident that $\mathrm{CD} 4{ }^{\text {lo/int }} \mathrm{CD} 8$ cells became the dominant precursors of DP cells from Fd 18 on. The number of $\mathrm{CD} 4{ }^{\text {hi }} \mathrm{CD}^{\mathrm{hi}}$ cells increased significantly from $24 \%$ at Fd 17 to more than $60 \%$ at D 0 (Tab 1). TCR expression on these cells also increased rapidly from $10.7 \%$ at $\mathrm{Fd} 17$, to $29 \%$ at $\mathrm{Fd} 18$, and to $54 \%$ at birth (Fig 3). This suggests that $\mathrm{CD} 4{ }^{\text {hi }} \mathrm{CD} 8{ }^{\text {hi }}$ cells have been generated substantively and further matured to express TCRat the later stage of gestation and at birth.
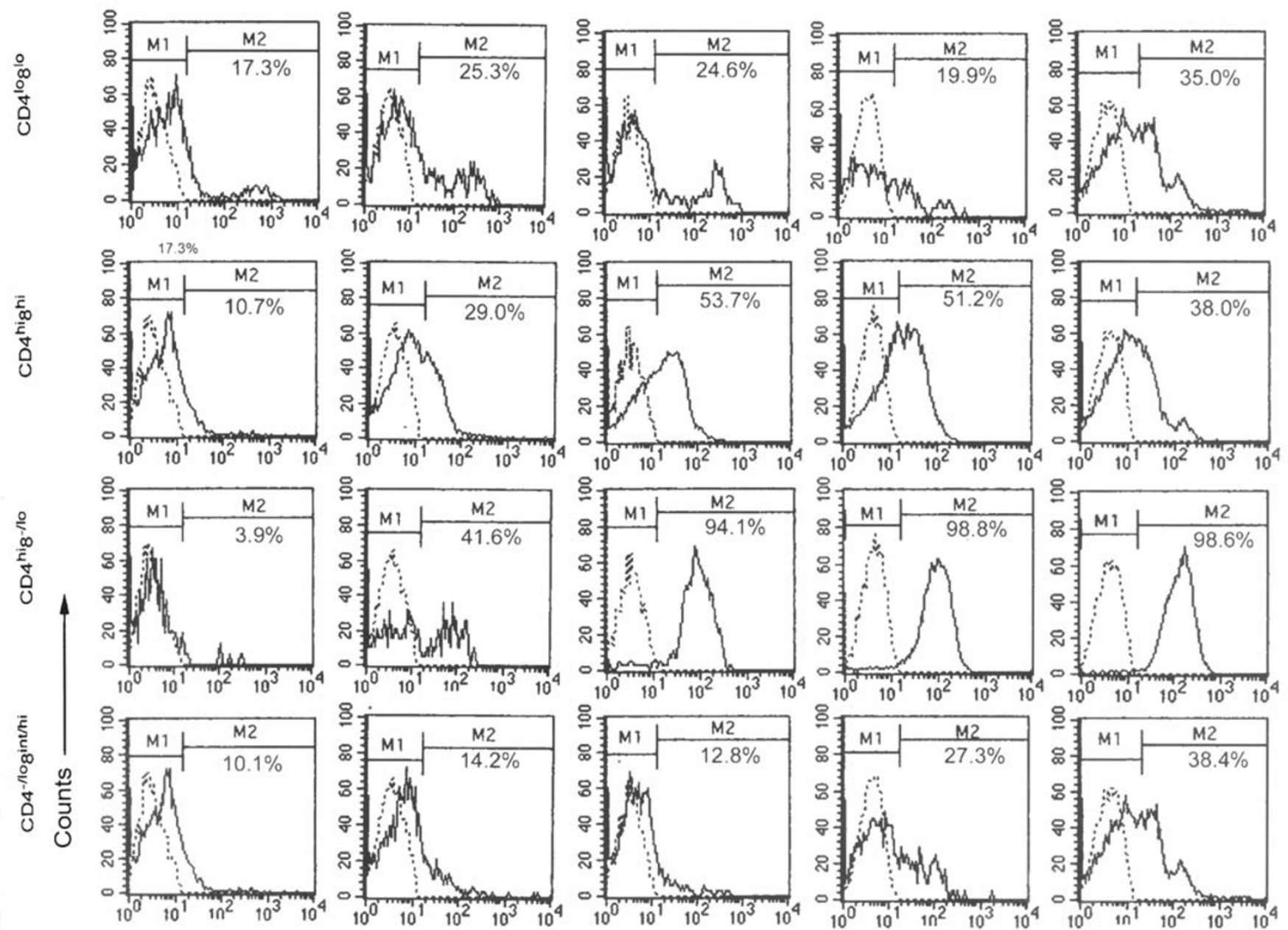

Fd 17
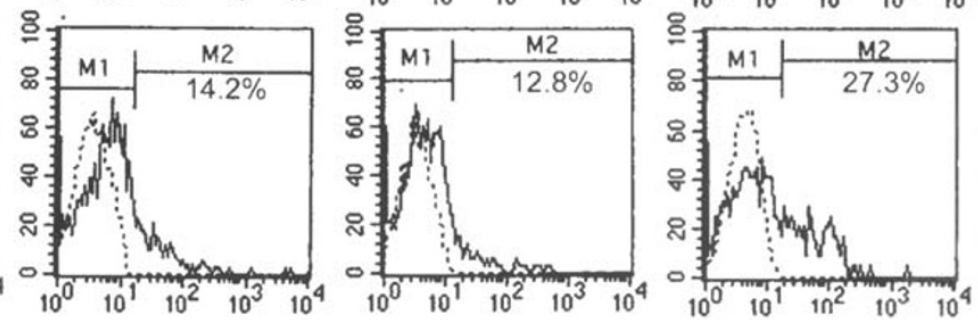

D 0

D 1

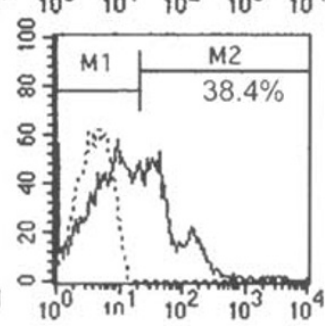

Fd 18

D 2

TCR-APC

Fig 3. Expression of TCR by CD4/CD8 subsets. Thymocytes were three-color stained with PE-conjugated anti-CD4, PerCPconjugated anti-CD8 and APC-conjugated anti-TCR. Based on CD4 and CD8 expression, seven thymocyte subsets were defined as in . Fluorescent intensity of histograms of TCR expression on four major subsets of CD $4^{\text {lo }} 8^{\text {lo }}(\mathrm{R} 4)$, CD $4^{\text {hi }} 8^{\text {hi }}($ R7), $\mathrm{CD} 4^{\text {hi }} 8^{-/ / 0}(\mathrm{R} 6)$ and CD4 $4^{-/ l o} 8^{\text {int/hi }}$ (R5) cells from Fd 17 to D 2 are shown. The histograms of TCR-APC overlapped with the isotype control in dotted lines. These data are representative of three separate experiments. 
Generation of $T C R^{+} C D 4^{-l l o} C D 8^{i n t / h i}$ cells during the third wave of cell proliferation

The third wave of cell proliferation occurred from D 2 to D 5 (Tab 1, Fig 2).At D 2 the $\mathrm{TCR}^{+} \mathrm{CD} 4 \mathrm{SP}$ cells increased, in coincidence with the decrease of CD $4{ }^{\text {hi }}$ CD ${ }^{\text {hi }}$ cells from D1 to D2. From D 3 on, both $\mathrm{CD} 4{ }^{\mathrm{hi}} \mathrm{CD} 8^{\mathrm{hi}}$ and $\mathrm{TCR}{ }^{+} \mathrm{CD} 4 \mathrm{SP}$ cells remained constant at about $70-80 \%$ and $10 \%$, respectively. The TCR expression on TCR ${ }^{+}$CD4 SP cells maintained at nearly $100 \%$ from D 1 to adulthood(Fig 3).At D 2, the $\mathrm{CD} 4^{-/ l o} \mathrm{CD} 8^{\text {int/hi }}$ cells started to increase gradually and reached about $5 \%$ at D 5 (Tab 1 , Fig 2 ). TCR expression on these $\mathrm{CD} 4^{-/ \mathrm{lo}} \mathrm{CD} 8^{\mathrm{int} / \mathrm{hi}}$ cells increased gradually with time, being about $40 \%$ positive at D2 (Fig 3), but the proportion of $\mathrm{TCR}^{+} \mathrm{CD} 4^{-/ / \mathrm{lo}} \mathrm{CD} 8^{\text {int/hi }}$ cells was still lower than that in adult mice $(75 \%)$ (data not shown). These $\mathrm{TCR}^{+} \mathrm{CD} 4^{-/ l o} \mathrm{CD} 8^{\text {int/hi }}$ cells generated in the third period of growth may represent newly emerged medullary type $\mathrm{TCR}^{+} \mathrm{CD} 8 \mathrm{SP}$ thymocytes.

In vitro differentiation of the transitional subsets of $\mathrm{TCR}^{-} \mathrm{CD} 4^{+} \mathrm{CD} 8^{-}$and $\mathrm{TCR} C \mathrm{CD} 4^{-} \mathrm{CD} 8^{+}$cells

In order to investigate the differentiation potential of $\mathrm{TCR}^{-} \mathrm{CD}^{+}{ }^{+} \mathrm{CD} 8^{-}$and $\mathrm{TCR}^{-\mathrm{CD}} 4^{-} \mathrm{CD}^{+}$cells at different fetal days, both subsets from mice of $\mathrm{Fd} 15$. $5, \mathrm{Fd} 16$ or $\mathrm{Fd} 17$ were isolated and cultured without any mitogenic stimuli or growth factors. After overnight incubation, the cells were recovered and analyzed by flow cytometry. The results showed that both cells from different days could give rise to TCR-DP cells after $24 \mathrm{~h}$ in vitro culture. Almost all the viable cells generated after culture were TCR $4^{+} \mathrm{CD} 8^{+}$phenotypically (Fig 4).

The differential pathways from DN to DP cells varied with mouse strains

The findings that immature CD4 and CD8 SP thymocytes dominated as precursors of DP cells at different gestation days were of interest and questioned whether it was unique in the BALB/c mice, therefore, the transitional stage from $\mathrm{DN}$ to $\mathrm{DP}$ cells in the fetal C57BL/6 mice was further investigated. Strikingly, this transition in the C57BL/6 mice was preferentially through the $\mathrm{TCR}^{-} \mathrm{CD} 8^{+} \mathrm{CD} 4^{-}$pathway (Fig 5). TCR $^{-} \mathrm{CD}^{+}{ }^{+} \mathrm{CD} 4^{-}$cells emerged at $\mathrm{Fd} 15$ and reached a maximum of about $15 \%$ in total cells at $\mathrm{Fd}$ 16, while $\mathrm{TCR}^{-} \mathrm{CD} 8 \mathrm{CD}^{+}{ }^{+}$cells remained below $1.5 \%$ throughout the gestation period (data not shown).

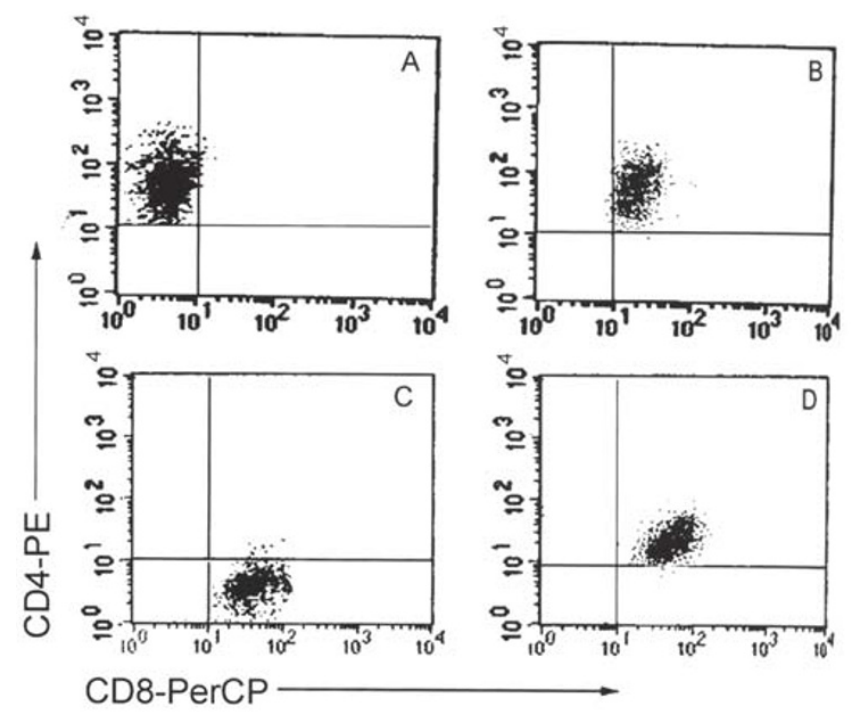

Fig 4. In vitro phenotypic differentiation of $\mathrm{CD} 34^{+} 8^{-}$and CD3$4^{-} 8^{+}$thymocytes from mice of $\mathrm{Fd} 16$. CD3 $4^{+} 8^{-}$and $\mathrm{CD} 348^{+}$cells were isolated by complement-mediated cytotoxicity method and panning method. Isolated cells $\left(1 \times 10^{6}\right.$ in $200 \mu \mathrm{l}$ RPMI 1640 medium with $10 \%$ FCS) were cultured overnight at $37^{\circ} \mathrm{C}$ for 24 h. Recovered cells were stained with PE-conjugated anti-CD4 and PerCP-conjugated anti-CD8 mAbs. CD3 $44^{+} 8^{-}$cells before and after culture are shown in Fig $4(\mathbf{A})$ and $(\mathbf{B})$, respectively. CD3 $44^{-} 8^{+}$cells before and after culture are shown in Fig $4(\mathbf{C})$ and (D), respectively. These data are representative of three separate experiments.

\section{DISCUSSION}

Thymocyte development begins at Fd 10 to 11 when hematopoietic stem cells colonize the thymus anlage[3, 10].This developmental process was usually analyzed on the basis of sequential appearance of four phenotypically defined subsets, i.e., CD4-CD8(DN), $\mathrm{CD}^{+} \mathrm{CD}^{+}$(DP), $\mathrm{CD} 4^{+} \mathrm{CD} 8^{-}(\mathrm{CD} 4 \mathrm{SP})$ and $\mathrm{CD}^{-} \mathrm{CD}^{+}{ }^{+}(\mathrm{CD} 8 \mathrm{SP})$ cells $[9,11]$. It is important physiological means to study thymocyte development by following the in vivo ontogenic process in mice. Penit's group described it as a discontinuous process in the C57BL/Ka mice, with two well defined growth periods from 13 to 18 days of fetal life and from 3 to 6 days after birth with progressive growth from 8 days to 2 weeks [4]. Our observations in the BALB/c mice from $\mathrm{Fd} 14$ to $\mathrm{D} 14$ gave similar results as well as novel findings. This process could be divided into 
four stages: 1) from $\mathrm{Fd} 14$ to $\mathrm{Fd} 17$; 2) from $\mathrm{Fd} 18$ to D 1 after birth; 3) from D 2 to D 5; 4) from D 6 on. Therefore, the differences lied in not only the time course each growth wave took place, but also a newly identified growth period. The different kinetics were probably attributed to the different strains of mice and the parameters used to identify the developing cells.

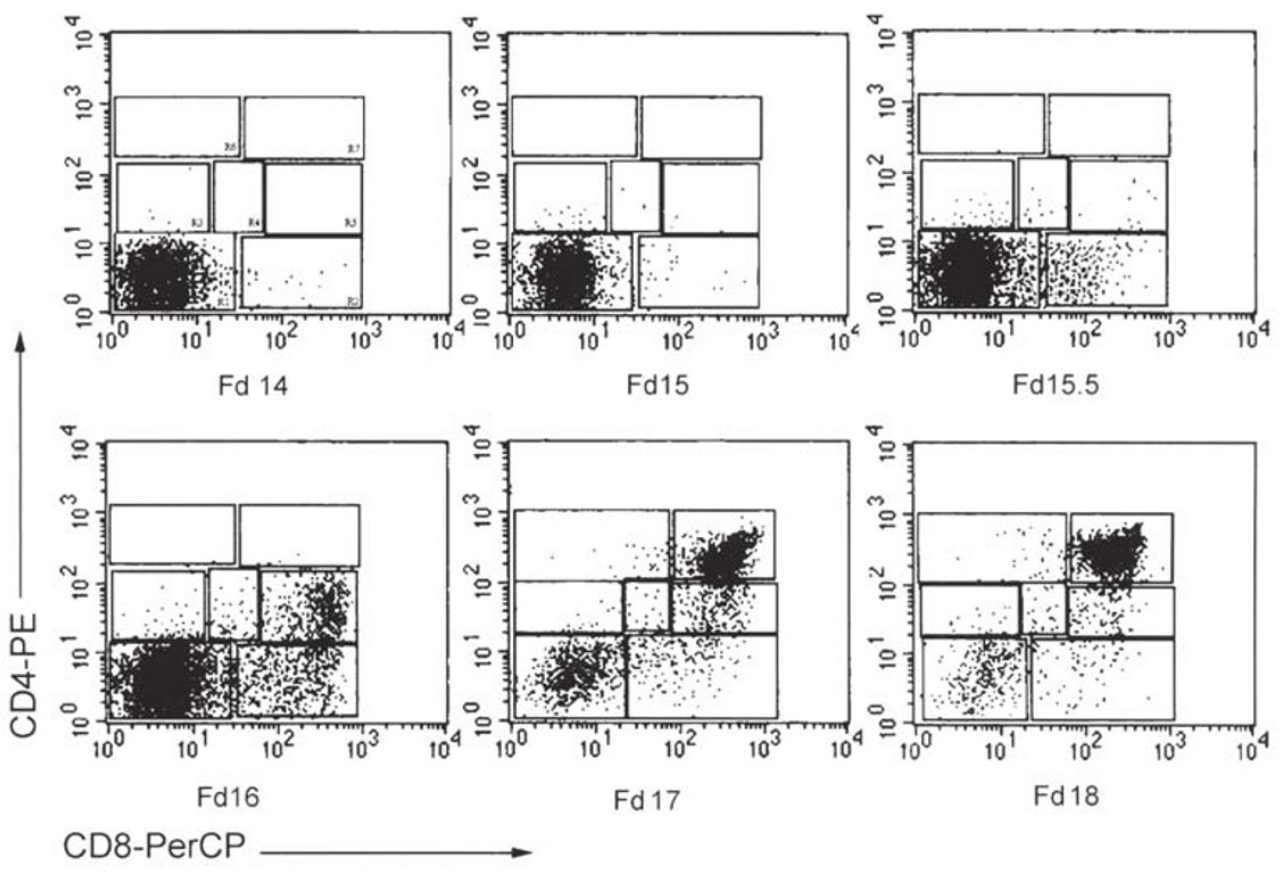

Fig 5. Kinetics of the expression of CD4 and CD8 molecules on thymocytes from fetal C57BL/6 mice. Thymocytes were stained triply with PE-conjugated anti-CD4, PerCP-conjugated anti-CD8 and APCconjugated anti-TCR. On the basis of CD4/CD8 fluorescent intensity, seven major transitional subsets were defined as same as in. These data are representative of three determinations.

More importantly, our studies demonstrated that each consecutive stage of thymocyte development during ontogeny coincided with the emergence of different subsets, which has not been reported before. In the first wave of proliferation from $\mathrm{Fd} 14$ to $\mathrm{Fd} 17$, the ISP cells were firstly generated and immediately differentiated into $\mathrm{CD} 4^{\mathrm{lo}} \mathrm{CD} 8^{\mathrm{lo}}$ and $\mathrm{CD} 4^{\mathrm{lo}} \mathrm{CD} 8^{\text {int }}$ cells, which in turn gave rise to $\mathrm{CD} 4^{\text {hi }} \mathrm{CD} 8^{\text {hi }}$ cells. $\mathrm{CD} 4^{\text {hi }} \mathrm{CD} 8^{\text {hi }}$ cells became the main subset in the first growth period. From Fd 18 to D 0, the proliferation slowed down and the total cell number remained constant while $\mathrm{CD} 4{ }^{\text {lo }} \mathrm{CD} 8{ }^{\text {lo }}$ and $\mathrm{CD} 4^{\text {lo }} \mathrm{CD} 8^{\text {int }}$ cells continued to develop into $\mathrm{CD} 4{ }^{\text {hi }} \mathrm{CD} 8{ }^{\text {hi }}$ cells. After birth, the development of thymocytes sped up again. $\mathrm{TCR}^{\mathrm{lo}} \mathrm{CD} 4^{\mathrm{hi}} \mathrm{CD} 8^{\mathrm{hi}}$ cells started to develop into $\mathrm{TCR}^{+} \mathrm{CD} 4 \mathrm{SP}$ cells via $\mathrm{TCR}^{+} \mathrm{CD} 4^{\mathrm{hi}} \mathrm{CD} 8^{\mathrm{lo} /-}$ cells. The generation of turned to be the characteristics of the second growth wave. At D 2, $\mathrm{TCR}^{+} \mathrm{CD} 8 \mathrm{SP}$ cells $\left(\mathrm{TCR}^{+} \mathrm{CD} 4^{-/ \mathrm{lo}} \mathrm{CD} 8^{\text {int/hi }}\right.$ cells) arose and gradually increased at the third peak of proliferation, suggesting that the major event at the third stage. In summary, the subsets of DP cells, $\mathrm{TCR}^{+} \mathrm{CD} 4 \mathrm{SP}$ cells and $\mathrm{TCR}^{+} \mathrm{CD} 8 \mathrm{SP}$ cells are sequentially generated in the three proliferation waves and characterized the hallmarks of the thymocyte kinetic development in fetal and neonatal mice.

Immature CD4 and CD8 single positive (ISP) thymocytes have been recognized and studied intensively during the 1980s and 1990s [12-16]. They have been shown to share great similarities, both being blastic, rapidly cycling, cortisone sensitive, localized in the outer thymic cortex and making up very little proportion in adult mice. They emerge after DN cells and before DP cells and are programmed to differentiate into DP cells. These similarities indicate their similar stages of differential pathways from DN to DP cells $[14,15,17]$. The choice of the "CD8 pathway" or 
“CD4 pathway" seems to be genetically destined, with one pathway dominant in one strain of mice[15, 16]. Most studies are focused on adult steady-state mice and so far there is seldom kinetic studies following in vivo ontogeny of the thymocytes. In our studies, the first subset derived from DN cells was TCR$\mathrm{CD} 4{ }^{\mathrm{lo}} \mathrm{CD} 8$ cells at $\mathrm{Fd} 14.5$, and they increased quickly during Fd 15-Fd 17 without further differentiation. Until Fd 17, TCR CD $4^{\text {lo }} \mathrm{CD} 8$ - cells were shown to differentiate rapidly into $\mathrm{TCR}^{-\mathrm{CD}} 4^{\mathrm{lo}} \mathrm{CD}^{10}$ and $\mathrm{TCR}^{-}$ $\mathrm{CD} 4^{\text {lo }} \mathrm{CD}^{\text {int }}$ cells. In contrast, $\mathrm{TCR}^{-} \mathrm{CD} 4^{-} \mathrm{CD} 8^{\mathrm{lo} / \mathrm{int}}$ cells appeared at $\mathrm{Fd} 15$, half a day later than TCR-CD $4^{\mathrm{lo}} \mathrm{CD} 8^{-}$ cells, and immediately developed into $\mathrm{TCR}^{+/}$$\mathrm{CD} 4{ }^{\text {lo }} \mathrm{CD} 8^{\text {hi }}$ cells, which subsequently gave rise to $\mathrm{TCR}^{+/-} \mathrm{CD} 4{ }^{\text {hi }} \mathrm{CD} 8^{\text {hi }}$ cells at Fd 17 . From Fd 18 on, TCR CD4 ${ }^{-} \mathrm{CD} 8^{\text {lo/int }}$ cells decreased markedly to an undistinguishable level and made no further contribution to the generation of DP cells. These findings showed that the direct precursors of DP cells were mainly CD8 ISP cells before Fd 17, and then became CD4 ISP cells. Accordingly, our studies suggest that both "CD4 ${ }^{+} \mathrm{CD}^{-} \mathrm{CD}^{-"}$ and "CD8 ${ }^{+} \mathrm{CD} 4^{-} \mathrm{CD} 3^{-1}$ pathways seem to play a dominant role during the differentiation from DN to DP cells at different fetal days of the BALB/c mice.

Further verification of the two differential pathways was done by short-term in vitro culture of both ISP cells isolated from mice of Fd 15 to Fd 17. They were shown to give rise to DP cells rapidly after overnight culture, confirming that they did act as two intermediate stages between DN and DP cells. Hugo et al have reported that both $\mathrm{CD} 4^{-} \mathrm{CD} 8^{+} \mathrm{CD} 3^{-}$and CD $4^{+}{ }^{-}$D ${ }^{-}{ }^{-} D 3^{-}$cells appeared as the intermediate precursors and generated DP cells in the CBA mice [18]. However, there were essential differences in the two mouse strains by the two laboratories. They observed that in the CBA mice $\mathrm{CD} 4^{+} \mathrm{CD} 8 \mathrm{CD} 3$ cells arose at $\mathrm{Fd} 15$ and reached a maximum of $6 \%$ at day 17 , and $\mathrm{CD} 4{ }^{-} \mathrm{CD} 8^{+} \mathrm{CD}^{-}$cells arose at $\mathrm{Fd} 16$ and reached a peak of $25 \%$ at $\mathrm{Fd} 16.5$. Thus, the $\mathrm{CD} 4{ }^{-\mathrm{CD}} 8^{+} \mathrm{CD} 3^{-}$ cells were dominant over $\mathrm{CD} 4^{+} \mathrm{CD} 8^{-} \mathrm{CD} 3^{-}$cells in the early thymocyte differentiation in the CBA mice[18]. By contrast, our findings in the BALB/c mice showed that TCR ${ }^{-}{ }^{-}{ }^{-}{ }^{-} 8^{+}$cells reached the peak of $13 \%$ at Fd 15 while TCR ${ }^{-}{ }^{+} 4^{+}{ }^{-} 8^{-}$cells appeared earlier but did not reach its maximum of $24 \%$ and became precursors until Fd 16. It suggests that both the CD8 and CD4 ISP cells function as intermediate stages during
$\mathrm{DN}$ to DP transition, as they do in the CBA mice, but the dominant pathway is through the CD4 ISP cells and the shift in precursors with embryonic days added more complexity to the developmental kinetics.

In order to investigate whether it was certain that both CD4 and CD8 ISP cells emerged along ontogenic thymocyte development in mice of different strains, we pursued further investigation in the fetal C57BL/ 6 mice. It was shown that $\mathrm{CD} 8^{+} \mathrm{CD} 4^{-} \mathrm{CD} 3^{-}$cells emerged at $\mathrm{Fd} 15$ and reached maximal at $\mathrm{Fd} 16$, while $\mathrm{TCR}^{-\mathrm{CD}} 8^{-\mathrm{CD}} 4^{+}$cells remained almost undetectable throughout gestation. In order to exclude the possibility of missing out TCR ${ }^{-} \mathrm{CD} 8^{-} \mathrm{CD} 4^{+}$cells due to their transitoriness we checked the mice every 6-10 h from Fd 14 to Fd 16, but no significant occurrence of TCR CD8 ${ }^{-} D 4^{+}$subset was observed. Therefore, it could be safely concluded that the TCR $\mathrm{CD}^{+} \mathrm{CD} 4{ }^{-}$pathway was overwhelmingly adopted in the C57BL/6 mice. The hypothesis that the dominance of ISP pathways in thymocyte development varies with mouse strains has been widely accepted. Undoubtedly, the present findings will help us gain a more comprehensive understanding of early thymocyte ontogeny. The factors that determine which route to take and the mechanisms underlying the genetical predetermination of strain variations in proportions of ISP thymocytes remain elusive. Resolution of this question will require illumination of signals regulating early thymocyte precursors to differentiate[17].

In order to investigate whether it was certain that both CD4 and CD8 ISP cells emerged along ontogenic thymocyte development in mice of different strains, thymocytes expressed varying levels of CD4 and/or CD8, an "absolute" DN subset of CD4CD8 cells was clearly identified. Following development, the proportion of this absolute DN subset decreased in the neonatal period, and virtually disappeared in adult mice (shown as R1 in Fig 2). It is, hence, logical to shift the setting of the gate window so as to define 4 major subsets of DN, DP, CD4 SP and CD8 SP cells. In this sense, the $\mathrm{TCR}^{+} \mathrm{CD} 4^{\mathrm{hi}} \mathrm{CD} 8^{\mathrm{lo} /-}$ cells and $\mathrm{TCR}^{+} \mathrm{CD}^{-/}$ ${ }^{\text {lo }} \mathrm{CD} 8{ }^{\text {int/hi }}$ cells generated during the second and third growth periods were actually the medullary type $\mathrm{TCR}^{+} \mathrm{CD} 4 \mathrm{SP}$ and $\mathrm{TCR}^{+} \mathrm{CD} 8 \mathrm{SP}$ cells identical with those of adults. However, we can't exclude at present that they may yet represent the transitional cells and that they require further differentiation steps before giving rise to medullary type SP thymocytes. Further 
studies of their functional competence will help to define their status.

\section{ACKNOWLEDGEMENTS}

This work was supported by grants from National 973 Program in China (No. G1999053904) and National Natural Sciences Foundation of China (No. 39730410).

\section{REFERENCES}

1. Le Douarin NM, Jotereau FV. Tracing of cells of the avian thymus through embryonic life in thterspecific chimeras. $J$ Exp Med 1975; 142:17-40.

2. Scollay R, Smith J, Stauffer V. Dynamics of early T cells: prothymocyte migration and proliferation in the adult mouse thymus. Immunol Rev 1986; 91:129-57.

3. Douagi I, Andre I, Ferraz JC, Cumano A. Characterization of $\mathrm{T}$ cell precursor activity in the murine fetal thymus: evidence for an input of $T$ cell precursors between days 12 and 14 of Fd. Eur. J Immunol 2000; 30:2201-10.

4. Penit C, Vasseur F. Cell proliferation and differentiation in the fetal and early postnatal mouse thymus. J Immunol 1989; 142:3369-77.

5. Ceredig R, MacDonald HR, Jenkinson EJ. Flow microfluorometric analysis of mouse thymus development in vivo and in vitro. Eur J Immunol 1983; 13:185-90.

6. Ge Q, Chen WF. Phenotypic identification of the subgroups of murine TCRabCD $4^{+} \mathrm{CD} 8$ thymocytes and its implication in the late stage of thymocyte development. Immunology 1999; 97:665-71.

7. Paterson DJ, Williams AF. An intermediate cell in thymocytes differentiation that expresses CD8 but not CD4 antigen. J Exp Med 1987; 166:1603-8.

8. Shortman K, Wilson A, Egerton M, Pearse M, Scollay R.
Immature $\mathrm{CD} 4{ }^{-} \mathrm{CD} 8^{+}$murine thymocytes. Cell Immunol 1988; 113:462-79.

9. Lucas B, Vasseur F, Penit C. Normal sequence of phenotypic transitions in one cohort of 5-bromo-2'-deoxyuridine- pulselabeled thymocytes. J Immunol 1993; 151:4574-82.

10. Fontaine-Perus JC, Calman FM, Kaplan C, LeDouarin NM. Seeding of 10-day mouse embryo thymic rudiment by lymphocyte precursors in vitro. J Immunol 1981; 126:2310-6.

11. Koichi A, Irving LW. The c-Kit ${ }^{+}$Maturation Pathway in Mouse Thymic T Cell Developmint: Lineages and Selection. Immunity 1996; 5:147-61.

12. Ceredig R, Dialynas DP, Fitch FW, MacDonald HR. Precursors of $\mathrm{T}$ cell growth factor producing cells in the thymus: ontogeny, frequency, and quantitative recovery in a subpopulation of phenotypically mature thymocytes defined by monoclonal antibody GK-1.5. J Exp Med 1983; 1158: 1654-71.

13. Kisielow P, Leiserson W, Von Boehmer H. Differentiation of thymocytes in fetal organ culture: analysis of phenotypic changes accompanying the appearance of cytolytic and interleukin 2-producing cells. J Immunol 1984; 133:111723.

14. MacDonald HR, Budd RC, Howe RC. A CD3- subset of CD4$8^{+}$thymocytes: a rapidly cycling intermediate in the generation of $\mathrm{CD}^{+} 8^{+}$cells. Eur J Immunol 1988; 18:519-23.

15. Hugo P, Waanders GA, Scollay R, Petrie HT, Boyd RL. Characterization of immature $\mathrm{CD}^{+}{ }^{+} \mathrm{CD} 8 \mathrm{CD}^{-}$thymocytes. Eur $\mathrm{J}$ Immunol 1991; 21:835-8.

16. Matsumoto K, Yoshikai Y, Moroi Y, Asano T, Ando T, Nomoto K. Two differential pathways from double-negative to double-positive thymocytes. Immunology 1991; 72:20-6.

17. Hugo P, Petrie HT. Multiple routes for late intrathymic precursors to generate $\mathrm{CD} 4^{+} \mathrm{CD}^{+}$thymocytes. Advances in molecular and cell biology 1992; 5:37-53.

18. Hugo P, Waanders GA, Scollay R, shortman K, Boyd RL. Ontogeny of a novel $\mathrm{CD} 4^{+} \mathrm{CD} 8^{-\mathrm{CD}} 3^{-}$thymocyte subpopulation: a comparison with $\mathrm{CD}^{-} \mathrm{CD}^{+} \mathrm{CD} 3^{-}$ thymocytes. Int Immunol 1990; 2:209-18. 